\title{
IMAGINING GOD
}

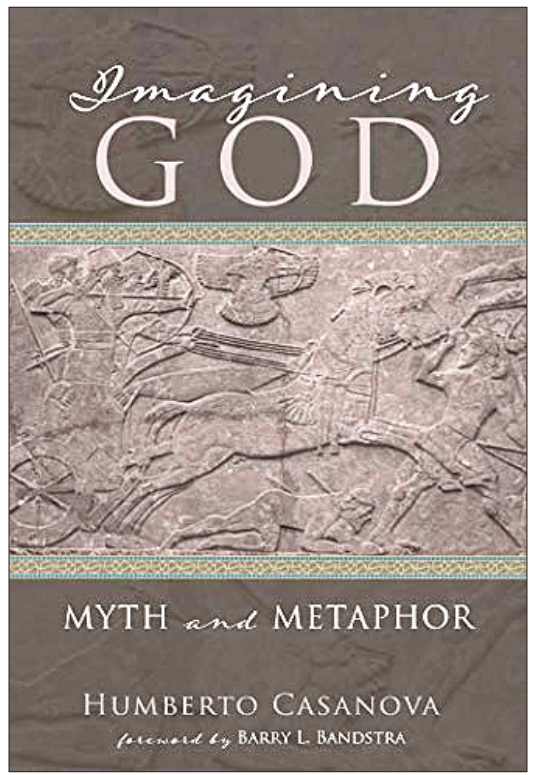

CASANOVA, HUMBERTO (2020). Imagining God. Myth and Metaphor. Eugene (OR): Wipf \& Stock, $340 \mathrm{pp}$., $37,44 €$ [ISBN: 978-1-5326-8818-8].

\author{
JOSÉ MANUEL LOSADA \\ Universidad Complutense de Madrid \\ jlosada@ucm.es
}

Como todo mensaje poético, el relato mítico recurre a los dos modos elementales de la comunicación literaria: la selección y la combinación. Ambos están basados respectivamente en las dos relaciones fundamentales que nuestro pensamiento establece (ora de modo diacrónico, ora de modo sincrónico) entre los objetos: la semejanza y la contigüidad. Mediante la semejanza, nuestro psiquismo descubre un parecido denominado analogía; mediante la contigüidad, descubre a su vez dos tipos 
de relaciones: una relación de correspondencia y una relación de designación generalizadora. De este parecido y de estas dos relaciones emanan las respectivas figuras literarias: metáfora o intersección de significado por coposesión de semas, metonimia o co-inclusión de un conjunto de semas y antonomasia o sinécdoque generalizadora por supresión parcial de semas.

La mayoría de las interpretaciones actuales de los relatos míticos son metafóricas. Se ha llegado incluso a identificar mito con metáfora: "Un mito es una metáfora que se desconoce a sí misma, que no se reconoce como metáfora. Prometeo robando el fuego de lo alto es un símbolo o metáfora perfecta del rayo. Pero si se toma como expresión de la realidad del rayo, esta metáfora es un mito" (Ortega y Gasset, Investigaciones psicológicas). Con gran sentido pedagógico, Platón recurría a una sucesión de metáforas (la alegoría - no mito - de la caverna) para describir la existencia de dos mundos: el sensible y el inteligible. La metáfora (y su correlato meta-lógico, la alegoría) es el recurso predilecto en toda disciplina didáctica para explicar ideas, teorías y conceptos: ilustra gráficamente algo complejo.

Sirvan estas reflexiones personales como preámbulo para celebrar debidamente la publicación del libro Imagining God: Myth and Metaphor. En efecto, este volumen incide plena y ajustadamente en una figura indispensable para la comprensión del mito. Nuestro mecanismo cognitivo busca entender áreas inexperimentadas y desconocidas a través de otras experimentadas y conocidas; con este fin toma prestadas imágenes y expresiones de nuestro entorno para construir una imagen del universo divino, sobre todo aquellas que lo hacen más humano: "teísmo - afirma Casanova en la Introducción - puede ser definido como la visualización del mundo divino mediante metáforas, en particular el antropomorfismo" (p. xviii). De ahí la paradoja: el hombre solo es capaz de hablar del mundo divino en términos humanos; pero la literatura ya nos tiene acostumbrados a asumir otras condiciones paradójicas (entre las cuales no es baladí la de presentar el mundo natural en términos lingüísticos).

Imagining God combina felizmente los conceptos de mito, metáfora y antropomorfismo aplicados a la Biblia (Antiguo y Nuevo Testamento). Movido por un acuciante "problema pastoral" (¿qué significa hablar de dioses y de teísmo?), Casanova recurre sin ambages a los términos de metáfora (más concretamente, a los de metáfora extendida y metáfora conceptual) para definir el mito (cf. "suma de metáforas y símbolos en forma narrativa que conforman el concepto de lo divino", p. 2; "género literario en el que contamos historias sobre los dioses", p. 162).

Una aportación crucial: la síntesis de nuestras historias sobre los dioses crea una metáfora conceptual, esto es, un concepto de Dios. Esta teoría no implica que Dios sea solo un concepto, sino que la mitocrítica solo puede estudiarlo como metáfora; más concretamente, como metáfora antropomórfica. El antropomorfismo consiste 
en un proceso que conceptualiza el ámbito divino en términos de nuestro mundo humano, esto es: "numerosas metáforas individuales procedentes del ámbito humano son utilizadas para construir la metáfora conceptual «dios es (súper) humano»" (p. 58). Esto es verificable en el "cuerpo" de Yahveh y otros dioses (Yahveh que "camina en el jardín de Edén", p. 62; Yahveh que "se desposa y procrea", p. 66; que "se arrepiente", p. 68, etc.). También merece atención la digresión sobre el "mundo divino". El autor pasa revista a la ambigüedad creada por el carácter personal o impersonal de los dioses, la aplicación de nuestras jerarquías y categorías al dominio divino: asambleas, héroes, cielo, infiernos (pp. 126-157).

Precisión con entidad propia: el principal antropomorfismo del teísmo es la metáfora del rey; "Dios es rey" (p. 163) o "los dioses son (como) reyes" (p. 168). Dado el contexto político y social de la Antigüedad, en el que la monarquía proveía un sinfín de imágenes y expresiones lingüísticas para la representación mental de la divinidad, "el mundo de los dioses era una réplica del mundo del antiguo Oriente Medio" (p. 163). El autor dedica páginas (quizá demasiadas y con excesivas citas apud, sin patencia de recurso a los textos de Oriente Medio) al nacimiento de la escritura acadia (indispensable para registrar contratos de todo tipo). Sigue una sensata explicación sobre la monarquía como "mito fundacional" (p. 168) de la antigua teología, tal y como muestran textos de la época: Atrahasis, El código de Hammurabi, Enûma Elish. Del reinado al imperio (extensión de la idea de supremacía, habitualmente coloreada de poderío sobrehumano) y a las metáforas subsiguientes: los dioses como guerreros imperiales semi-divinos en Mesopotamia, Egipto, Siria, Palestina y amplios terrenos de la ribera mediterránea.

Andando el tiempo, aparecerían otros relatos míticos, como los de Eusebio en la Historia eclesiástica y la Vida de Constantino, que introducen una versión cristiana del mito del dios guerrero (Constantino, nuevo Moisés, peleando contra Majencio, imagen del faraón, pp. 193-194). El ejemplo está bien traído. Sin embargo, el autor lo manipula en el quinto capítulo ("Critical Assessment of the King Metaphor") para aplicar literalmente su concepto de metáfora ficticia a la religión cristiana, entonces y ahora. Un ejemplo: "La toxicidad de la metáfora del monarca es patente en el hecho de que los cristianos en los Estados Unidos gozan del lujo de vivir en un país supuestamente democrático y, sin embargo, la teología cristiana sigue provocando a sus ciudadanos a anhelar la Segunda Venida de un dictador escatológico" (p. 207). Frases como esta adolecen de un apriorismo y de una ausencia de deducción crítica que invitarían a abandonar la lectura (si el lector se dejara llevar, como el autor, por instintos viscerales). La incoherencia es patente: Casanova ha abandonado, sin motivo, su propia y principal consideración del mito como género literario para pasar a un terreno ajeno a la investigación académica que estaba brillantemente conduciendo. 
De ahí su sectarismo o, cuando menos, falta de seriedad científica. Cuando la ideología mueve la investigación, falla la verdad.

En otro orden de cosas, Casanova sostiene que el mito es "el cúmulo de narraciones y expresiones que sirven para formar una metáfora conceptual" y que la "suma de todas estas narraciones forma el concepto de lo divino". Considero esta definición parcial. El mito no habla solo de los dioses; también de nosotros mismos. Es más, sin nosotros no hay mito, porque este irrumpe cuando dos personajes de diversa naturaleza, uno sobrenatural, otro natural, entran en contacto.

Con todo, el balance es positivo: la claridad expositiva con la que Casanova expone su hipótesis personal (la metáfora antropomórfica de Dios como rey a partir de los relatos míticos de Oriente Medio) y la buena apoyatura textual en la mayoría de los casos aportados aconsejan tenerla en cuenta en el horizonte de la actual mitocrítica. 